\title{
Impact of Septoplasty on Oxidative DNA Damage Levels in Patients with Marked Nasal Septal Deviation
}

\author{
Vural Fidan ${ }^{1 *}$, Handan Koyuncu ${ }^{1}$ and Hakan Alp ${ }^{2}$ \\ ${ }^{1}$ Eskisehir City Hospital Otorhinolaryngology Dept. Eskisehir/ Turkey. \\ ${ }^{2}$ Van University, Biochemistry Dept. Van/ Turkey.
}

*Corresponding Author: Vural Fidan, Associate Professor, Department of Otorhinolaryngology, Cavdarlar Street, Eskisehir, 26080, Turkey.

Received date: February 08, 2021; Accepted date: March 08, 2021; Published date: May 10, 2021

Citation: Fidan V, Koyuncu H. and Hakan Alp. (2021) Impact of Septoplasty on Oxidative DNA Damage Levels in Patients with Marked Nasal Septal Deviation. J.Clinical Otorhi 3(2); DOI: 10.31579/2692-9562/024

Copyright: (C) 2021, Vural Fidan. This is an open access article distributed under the Creative Commons Attribution License, which permits unrestricted use, distribution, and reproduction in any medium, provided the original work is properly cited.

\section{Abstract}

Objectives:Nasal septal deviation (NSD) is a common dilemma which cause nasal obstruction. Septoplasty is usually accomplished to solve nasal obstruction in patients with NSD. NSD is related strongly with hypoxia. Hypoxic conditions increase oxidative DNA damage in cells.

This study aimed to investigate the effect of septoplasty on the level of antioxidant agents in patients with marked NSD.

Methods: Sixty-one patients who submitted to septoplasty were involved in our prospective investigation.

Results: The difference between the pre- and postoperative levels of MDA and 8-OHdG/106 dG was statistically significant.

Conclusions: Septoplasty is an elective surgery performed to prevent the decrease in quality of life due to nasal obstruction and frequent respiratory tract infections in patients with NSD. As seen in this study, septoplasty is an urgent surgery that should be performed urgently to prevent DNA damage in patients with NSD.

Key Words: nasal septal deviation, septoplasty, 8-OHdG, DNA oxidation, lipid peroxidation, oxidative stress.

\section{Introduction}

Nasal obstruction is an usual ailment of subjects applying to otorhinolaryngologists and the leading argument of nasal obstruction is nasal septal deviation (NSD) [1]. Almost 50\% of the respiratory tract obstruction originates at the nasal area [2]. Respiratory tract obstruction may be increased in case of nasal obstruction due to NSD.

There are many studies that shown the nasal obstructions could result to chronic hypoxia [3, 4]. Chronic hypoxia causes the reactive oxygen species (ROS) [5]. ROS are extremely reactive particles that interact with nucleic acids, lipids, and proteins and are regarded to have an improved DNA oxydation, giving arise to cytotoxic tissue destruction. Lipid peroxidation induced by ROS concludes in many unsteady, disintegrated mixtures, with the most significant one being malondialdehyde (MDA), an adequate declarative of lipid peroxidation [6]. But then, ROS are intimately conjoined with DNA rupture and infrastructure alteration [7]. For this intention, the utilisation of any marker of DNA oxidation, such as 8-hydroxy-2 -deoxyguanosine [8-OHdG], to measure oxidative stress is of implication [8]. It is well constituted that oxidative stress is correlated with hypoxia $[9,10]$. Although antioxidant degrees were higher in subjects with hypoxia than subjects with normoxia. There is no study, as far as we are interested, about the effect of septoplasty on antioxidant condition in patients with major NSD. We accomplished this survey to sustain whether there is a relation between NSD and serum MDA and leukocyte 8-OHdG degrees before and after septoplasty.

\section{Materials and methods}

Sixty-one patients (34 male, age range being 21-46 years) who submitted to septoplasty for major NSD between May 2015 and April 2017 at the otolaryngology branch of 2nd stage hospital were involved in our investigation. The patients with noticed NSD were identified by anterior rhinoscopy and nasal endoscopy (Karl Storz, Germany). Then nasal apetures, nasopharynx, oropharynx and larynx were assessed by a flexible fiberoptic endoscope (Karl Storz 11001RD1, Germany). The other dilemmas engendering upper respiratory tract blockage such as nasal polyposis, adenoid vegetation and hypertrophied tonsils were eliminated from this survey. All subjects had major NSD and no chronic diseases such as diabetes mellitus, hypertension. In preoperative interval and 3 
months after septoplasty, the blood specimens were gathered $(2 \mathrm{~mL}$ serum for MDA assessment, $3 \mathrm{~mL}$ whole blood for $8-\mathrm{OHdG} / \mathrm{dG}$ measurement). All samples were preserved at $-80^{\circ} \mathrm{C}$ up to test time.

DNA isolation from leukocytes was assembled by the procedure of Miller and coworkers [11]. Agilent 1100 modular pattern was used to assess the high-pressure liquid chromatographic analysis (Phenomenex, CA) (12). Serum MDA analysis was validated by Khoschsorur et al using fluorescence detector (13). IBM SPSS 18.0 was used for statistical analysis. Sample T-test was used, and $\mathrm{P}<0.05$ was regarded statistically meaningful.

\section{Results}

Excessive bleeding was seen in two patients and septal perforation was seen in one patient. The difference between the pre- and postoperative levels of MDA and 8-OHdG/106 dG was statistically significant (P < 0.05), and it is shown in Supplementary Table 1.

\begin{tabular}{|l|l|l|l|l|l|l|}
\hline & & \%95 CI of Means & & \multicolumn{2}{l|}{ \%95 CI of Means } \\
\hline & $\begin{array}{l}\text { MDA }(\mu \mathrm{M}) \text { Mean } \\
\pm \text { SD }\end{array}$ & Low & High & $\begin{array}{l}\text { 8-OHdG/106 dG } \\
\text { Mean } \pm \text { SD }\end{array}$ & Low & High \\
\hline $\begin{array}{l}\text { Before Operative } \\
\text { Period }\end{array}$ & $11.30 \pm 2.19 *$ & 10.14 & 12.46 & $2.19 \pm 0.98 *$ & 2.07 & 2.31 \\
\hline Post Operative Period & $5.42 \pm 1.87 *$ & 4.38 & 6.04 & $0.53 \pm 0.39 *$ & 0.41 & 0.65 \\
\hline
\end{tabular}

Supplementary Table 1: The Comparison of Pre- and Postoperative MDA and 8-OHdG/106 dG Levels of the Patients With NSD $\% 95$ CI (confidence interval). SD : standard deviation. *: Statistically significant difference at the order of $\mathrm{P}<0.05$.

\section{Discussion}

Nasal septal deviation is a common complaint of patients presenting to ear nose throat clinics. It may be ignored sometimes but it is a very important nasal disease, because of its probable complications such as pulmonary hypertension, cor pulmonale and alveolar hypoventilation [1517]. It should be kept in mind for differential diagnosis of chronic hypoxia [17]. Previous studies have shown that chronic hypoxia is associated with many oxidative stress problems [18]. Nasal obstruction is one of the causes of hypoxia, mechanisms such as oxidative stress commonly seen in hypoxic patients must be considered in patients with NSD. The present study was planned to investigate the effect of septoplasty, used for NSD therapy, on oxidative damage.

Since in hypoxia is maintained, an increased ROS production is inevitable $[19,20]$. ROS are produced in all aerobic cells. However, if an overproduction occurs and it becomes over antioxidant capacity, biomolecules such as DNA, lipids, proteins, and carbohydrates are oxidized, resulting in damage caused by this oxidative stress [21]. ROS produce lipid hydroperoxides affecting polyunsaturated fatty acids. The breakdown of these hydroperoxides yields aldehyde groups, of which the majority is MDA. It is used as a marker for lipid peroxidation [22]. Several methods may be used for MDA determination, with the common one being spectrophotometric method based on the colored complex with thiobarbituric acit [23]. We measured MDA by the high-pressure liquid chromatographic (HPLC) method, including fluorescence detector (FLD) [24]. It is well known that ROS are effective on the DNA. The base modification is the most important one. A well-known base modification is oxidation of D-guanosine residue to 8-hydroxydeoxyguanosine (8OGdG), which is a good marker for DNA oxidation [25]. This oxidation product can be determined in body fluids such as serum and urine. Serum or urine 8-OGdG measurement can show the oxidative DNA damage. However, the determination of the oxidation on DNA molecule itself (not free ones) is more important. For this reason, in the present study, after we isolated DNA from leukocytes and hydrolyzed it with acid, 8-OGdG has been determined in that material. Although there are some disadvantages of acid hydrolysis, it is simply applied when compared to enzyme hydrolysis. In addition, during enzymatic hydrolysis, there may be some other oxidations due to $\mathrm{pH}$ changes, which may affect 8-OHdG measurement [26]. It is also well known that HPLC- electrochemical detector is the most convenient method for $8-\mathrm{OHdG}$ measurement [26]. It has been reported that ROS increase in patients with hypoxia caused by different diseases and that lipid peroxidation increases, resulting in decrease in antioxidant enzyme capacity [27].
Septoplasty is an elective surgery performed to prevent the decrease in quality of life due to nasal obstruction and frequent respiratory tract infections in patients with NSD. As seen in this study, septoplasty is an urgent surgery that should be performed urgently to prevent DNA damage in patients with NSD.

There is no study about impact of septoplasty on oxidative damage in NSD patients. Our results show that the preoperative MDA levels are higher than those in postoperative period $(\mathrm{P}<0.01)$, which exhibits that septoplasty decreases lipid peroxidation. Similarly, that the preoperative $8-\mathrm{OHdG}$ levels are higher than those in postoperative period $(\mathrm{P}<0.01)$ can be considered as lowering effect of septoplasty on the DNA oxidative damage due to ROS. As a result, septoplasty decreases both DNA oxidation and lipid peroxidation as well. But new studies with larger case numbers are needed to confirm this result and explain the pathophysiology.

\section{References}

1. Unlu I, Kesici GG, Oneç B, Yaman H, Guclu E. (2016) The effect of duration of nasal obstruction on mean platelet volume in patients with marked nasal septal deviation. Eur Arch Otorhinolaryngol. 273(2):401-5.

2. Proctor DF. (1977) The upper airways. I. Nasal physiology and defence of the lungs. Am Rev Respir Dis. 115: 97-129

3. Markovitz GH, Colthurst J, Storer TW, Cooper CB. (2010) Effective inspired oxygen concentration measured via transtracheal and oral gas analysis. Respir Care. 55(4):453-9.

4. Yilmaz MD, Onrat E, Altuntaz A, Kaya D, Kahveci OK, Ozel O et al. (2005) The effects of tonsillectomy and adenoidectomy on pulmonary arterial pressure in children. Am J Otolaryngol. 26;1821.

5. Cheng RW, Yusof F, Tsui E, Jong M, Duffin J, Flanagan JG, Fisher JA, Hudson C. (2016) Relationship between retinal blood flow and arterial oxygen. J Physiol. 594(3):625-40.

6. Ottolenghi S, Rubino FM, Sabbatini G, Coppola S, Veronese A, Chiumello D, Paroni R. (2019) Oxidative Stress Markers to Investigate the Effects of Hyperoxia in Anesthesia. Int J Mol Sci. 20(21):5492.

7. Kang S, Lim Y, Kim YJ, Jung ES, Suh DH, Lee CH, Park E, Hong J, Velliquette RA, Kwon O, Kim JY. (2019) Multivitamin and Mineral Supplementation Containing Phytonutrients Scavenges Reactive Oxygen Species in Healthy Subjects: A Randomized, Double-Blinded, Placebo-Controlled Trial. Nutrients. 11(1):101. 
8. Cooke MS, Evans MD, Burd RM, Patel K, Barnard A, Lunec J, Hutchinson PE. (2001) Induction and excretion of ultravioletinduced 8-oxo-2'-deoxyguanosine and thymine dimers in vivo: implications for PUVA. J Invest Dermatol. 116(2):281-5.

9. Yamauchi M, Nakano H, Maekawa J, et al. (2005) Oxidative stress in obstructive sleep apnea. Chest. 127:1674-1679

10. Esterbauer H, Schaur RJ, Zollner H. (1991) Chemistry and biochemistry of 4- hydroxynonenal, malonaldehyde and related aldehydes. Free Radic Biol Med. 11:81-128

11. Miller SA, Dykes DD, Polesky HF. (1988) A simple salting out procedure for extracting DNA from human nucleated cells. Nucleic Acids Res. 16:1215

12. Armstrong D. (1998) Free Radical and Antioxidant Protocols. Totowa, NY: Human Press.

13. Khoschsorur GA, Winklhofer-Roob BM, Rabl H, et al. (2000) Evaluation of a sensitive HPLC method for the determination of malondialdehyde, and application of the method to different biological materials. Chromatographia. 52:181-184

14. Yu SS, Mei KD, Lin YS. (2013) Does airway integrated nasal packing after septal surgery improve body oxygenation? Rhinology. 51(3):243-8.

15. Uluyol S, Kilicaslan S, Gur MH, Karakaya NE, Buber I, Ural SG. (2016) Effects of Nasal Septum Deviation and Septoplasty on Cardiac Arrhythmia Risk. Otolaryngol Head Neck Surg. 155(2):347-52.

16. Caglar O, Aksit E. (2018) Evaluation of Heart Functions With Detailed Echocardiogram in Patients With Septum Deviation. $J$ Craniofac Surg. 29(8):2148-2152.

17. Celiker M, Cicek Y, Tezi S, Ozgur A, Polat HB, Dursun E. (2018) Effect of Septoplasty on the Heart Rate Variability in Patients With Nasal SeptumDeviation. J Craniofac Surg. 29(2):445-448.

18. McGarry T, Biniecka M, Veale DJ, Fearon U. (2018) Hypoxia, oxidative stress and inflammation. Free Radic Biol Med. 125: 1524.

19. Tretter L, Patocs A, Chinopoulos C. (2016) Succinate an intermediate in metabolism, signal transduction, ROS, hypoxia, and tumorigenesis. Biochim Biophys Acta. 1857(8):1086-1101.

20. Semenza GL, Prabhakar NR. (2018) The role of hypoxiainducible factors in carotid body (patho) physiology. $J$ Physiol. 596(15):2977-2983.

21. Kirkham PA, Barnes PJ. (2013) Oxidative stress in COPD. Chest. 144(1):266-273.

22. Gawel S, WM, Niedworok E, Wardas P. (2004) Malondialdehyde (MDA) as a lipid peroxidation marker. Wiad Lek. 57:453-455

23. Draper HHHM. (1990) Malondialdehyde determination as index of lipid peroxidation. Methods Enzymol. 186:421-431

24. Mendes R, Cardoso C, Pestana C. (2009) Measurement of malondialdehyde in fish: a comparison study between HPLC methods and the traditional spectrophotometric test. Food Chem. 112:1038-1045

25. Mecocci P, Macgarvey U, Kaufman AE, et al. (1993) Oxidative damage to mitochondrial-DNA shows marked age-dependent increases in human brain. Ann Neurol. 34:609-616

26. Shigenaga MK, Aboujaoude EN, Chen Q, et al. (1994) Assays of oxidative DNA-damage biomarkers 8-oxo-2'-deoxyguanosine and 8-oxoguanine in nuclear-DNA and biological-fluids by highperformance liquidchromatography with electrochemical detection. Method Enzymol. 234:16-33

27. Rauchová H, Vokurková M, Koudelová J. (2012) Hypoxiainduced lipid peroxidation in the brain during postnatal ontogenesis. Physiol Res. 61(Suppl 1):S89-101. 